Hydrol. Earth Syst. Sci., 13, 2039-2053, 2009

www.hydrol-earth-syst-sci.net/13/2039/2009/

(C) Author(s) 2009. This work is distributed under

the Creative Commons Attribution 3.0 License.

\title{
Hydropedological model of vertisol formation along the Gulf Coast Prairie land resource area of Texas
}

\author{
L. C. Nordt and S. G. Driese \\ Department of Geology, Baylor University, Waco, Texas 76798, USA \\ Received: 31 March 2009 - Published in Hydrol. Earth Syst. Sci. Discuss.: 30 April 2009 \\ Revised: 22 October 2009 - Accepted: 22 October 2009 - Published: 3 November 2009
}

\begin{abstract}
Vertisols are clayey soils containing slickensides and wedge-shaped aggregates formed by shrink-swell processes in seasonally wet climates. The dynamic distribution of macro- and microvoids as a by-product of this unique pedoturbation process, accompanied by microtopographic lows and highs (gilgai), mitigate our ability to make accurate and precise interpretations of aquic and hydric conditions in these problem soils. We studied Vertisols across a subhumid to humid climosequence to assess the formation of redoximorphic features on shallow, linear (nondepressional) landscape positions in response to varying levels of rainfall. Approximately $1000 \mathrm{~mm}$ of mean annual precipitation (MAP) is required to form soft iron masses that then increase in abundance, and to shallower depths, with increasing rainfall. Soft iron masses with diffuse boundaries become more abundant with higher rainfall in microlows, whereas masses with nondiffuse boundaries become more common in microhighs. Most soft iron masses form in oxygenated ped interiors as water first saturates and then reduces void walls where iron depletions form. In contrast, at least $1276 \mathrm{~mm}$ of MAP is needed to form iron pore linings in both microlow and microhigh topographic positions. Iron depletions do not correlate with rainfall in terms of abundance or depth of occurrence. The quantity of crayfish burrows co-varies with rainfall and first appears coincidentally with soft iron masses in microlows near $1000 \mathrm{~mm}$ of MAP; they do not appear until nearly 1400 $\mathrm{mm}$ of MAP in microhighs. Dithionite-citrate extractable and ammonium-oxalate extractable iron oxides increase systematically with rainfall indicating more frequent episodes of iron reduction and precipitation into pedogenic segrega-
\end{abstract}

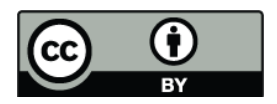

Correspondence to: L. C. Nordt (lee_nordt@baylor.edu) tions. The sum of our data suggests that Vertisols forming in the Coast Prairie of Texas with MAP greater than $1276 \mathrm{~mm}$ should be classified as aquerts because of the presence of aquic conditions. These same soils may also meet the definition of hydric as one criterion for the identification of Federally-protected wetlands. However, there is a considerable disjunct between protracted periods of saturation and limited periods of reduction in these soils. Based on the distribution of redoximorphic features in the study area, regional water table data, and recent electrical resistivity data from a nearby upland Vertisol, non-Darcian bypass flow is the principle mechanism governing the flux of water through deep cracks where water first accumulates and then persists in microlow bowls at depths of 1 to $2 \mathrm{~m}$.

\section{Introduction}

Vertisols cover approximately $132000 \mathrm{~km}^{2}$ of land area in the coterminous USA (Guo et al., 2006) where seasonal wetness regulates the shrink-swell processes critical to the formation of these clayey soils (Wilding and Tessier, 1988). In turn, these unique properties and affiliated wetness conditions present numerous agricultural and engineering challenges worldwide (Dudal and Eswaran, 1988; Coulombe et al., 1996; Nordt et al., 2004). Determining the duration of saturation needed to induce anaerobic conditions has been controversial, leading to the recognition of Vertisols as one of the problem soils for identifying either taxonomicallydefined aquic soil moisture regimes or hydric soils as a criterion for identifying jurisdictional wetlands (Comerma, 1985; Griffin, 1991; Jacob et al., 1997). First, by definition, Vertisols are seasonally wet because they must desiccate during

Published by Copernicus Publications on behalf of the European Geosciences Union. 
at least some part of the year in order for cracks and slickensides to form from shrink-swell pressures. Defining aquic soil moisture regimes and hydric conditions is notoriously difficult for seasonally wet soils and often depends on qualitative assessment of iron redoximorphic features. Second, there is uncertainty as to which soft iron masses form in relation to the modern soil hydroperiod as contemporaneous features. Third, Vertisols possess a spatial and temporal dynamic distribution of micropores and macropores contributing to water flux in non-Darcian terms. This is expressed as bypass flow where water is transported under saturated conditions along macropores adjacent to unsaturated ped interiors. These factors can lead to disequilibrium between periods of saturation and reduction when using elemental iron as a proxy for oxygen deficiencies. Fourth, microtopographic cyclicity (gilgai and subsurface waviness) generates difficulties determining when both the microlow and microhigh are saturated/anaerobic and how much of the pedon cycle must meet these conditions for the soil to be considered aquic or hydric.

One of the most widespread regions in the world containing Vertisols is along the Gulf Coast Prairie of Texas where they are mapped on shallow, planar slopes, and to a lesser extent in depressional landscape positions. Much of the region has been cultivated for decades, with some of these lands converted to other nonagricultural uses (Griffin, 1991; Nordt and Wilding, 2009). Knowledge of wetness conditions of Vertisols in this region has been gained from casual observation of morphological features during soil survey mapping, or from water table monitoring of one or more random locations (see Griffin, 1991 and Jacob et al., 1997). As such, there has been much confusion in the classification and mapping of Vertisols regarding wetness conditions, compounded by a lack of understanding of the genesis of wetness features in these soils.

The purpose of this paper is to provide a hydropedological conceptual model of Vertisol formation based on evidence from the systematic evaluation of field and laboratory properties diagnostic of wetness across a subhumid to humid Vertisol climosequence in the Gulf Coast Prairie Land Resource Area of Texas. The model is strengthened by the incorporation of monitoring data from two previous hydromorphological studies in the Coast Prairie, and by recent electrical resistivity work tracking wetness conditions on a nearby upland Vertisol.

\section{Setting and methods}

The study area covers the Beaumont Formation of Texas, a coastwise fluvial-deltaic terrace as part of the Gulf Coast Prairie Major Land Resource Area (Fig. 1). Mean annual precipitation (MAP) ranges from 755 to $1437 \mathrm{~mm}$ and traverses the ustic/udic soil moisture boundary $(\sim 900 \mathrm{~mm})$ within a hyperthermic $\left(>22^{\circ} \mathrm{C}\right.$ ) soil temperature regime (see

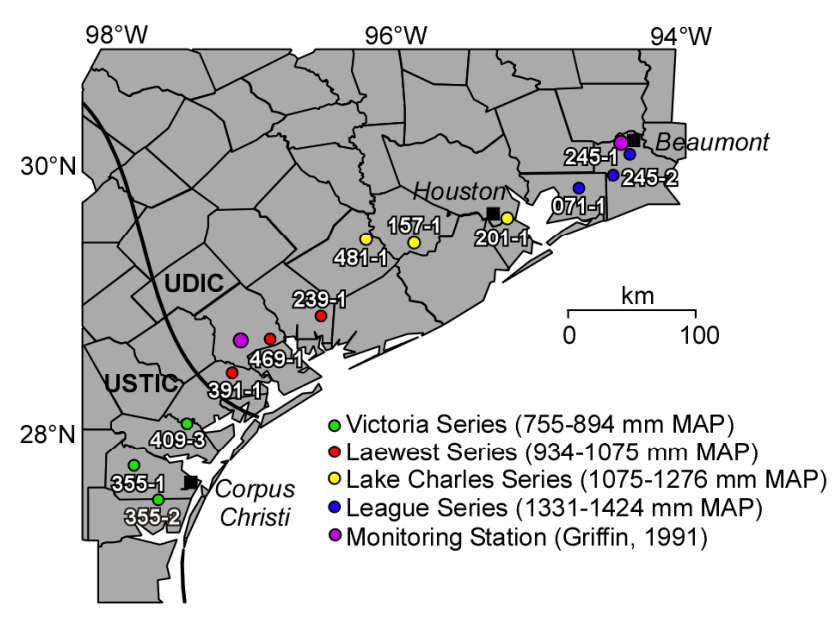

Fig. 1. Map showing locations of the twelve Vertisol pedon sample sites of this study and the two water table monitoring localities of Griffin (1991), in relation to mean annual precipitation (MAP) and taxonomically-defined soil moisture regimes (Soil Survey Staff, 1999) on the Beaumont Formation within the Gulf Coast Prairie Major Land Resource Area of Texas.

Soil Survey Staff, 1999). Vegetation in the region is prairie and covered mostly by warm season grasses (USDA-SCS, 1981). The regional topography is dominated by nearly level, linear surfaces with isolated depressions as evidenced by numerous county soil surveys (e.g. Miller, 1997) and other geologic maps (e.g. Barnes, 1987). Interdistributary floodbasin deposits comprise the parent material of the mapped Vertisols with Alfisols and Mollisols occurring on adjacent meander ridges. Soils on the Beaumont Formation are late Pleistocene in age (Blum and Price, 1994). Thus, the study area constitutes a climosequence because the soil forming factors of biota, topography, parent material and time are held relatively constant.

We studied twelve pedons located in nondepressional landscape positions on the Beaumont Formation, with three in the Ustic soil moisture regime (Victoria series), and nine in the Udic soil moisture regime (three each in the Laewest, Lake Charles, and League series) (Fig. 1; Table 1). Two previous water-table monitoring sites are located along the climosequence: one within the area of the Laewest series near the Ustic/Udic boundary and the other within the area of the League series on the eastern part of the study area (Fig. 1). These Vertisols have A-Bss(g)-Bssk(g) profiles with mollic epipedons and cambic or calcic subsurface diagnostic horizons (Soil Survey Staff 2009; http://ssldata.nrcs.usda. gov). However, microlows tend to have thicker sola and surface horizons and greater depth to carbonate than microhighs (Fig. 2a, b). With no particular correlation to climate, percent organic carbon in the microlows of surface horizons ranges from approximately 1.6 to $3.4 \%$, whereas in the microhighs organic carbon content ranges from 1.4 to $2.9 \%$. Reaction is slightly acidic in surface horizons of microlows above 
Table 1. Soil characteristics of the Vertisol climosequence in the Gulf Coast Prairie Land Resource area of Texas.

\begin{tabular}{|c|c|c|c|c|c|c|c|c|c|}
\hline Soil Series $^{\mathrm{a}}$ & Pedon $\mathrm{ID}^{\mathrm{b}}$ & County & $\begin{array}{c}\text { Lat/Long } \\
\left({ }^{\circ} \mathrm{C}\right)\end{array}$ & $\begin{array}{r}\mathrm{MAP}^{\mathrm{C}} \\
(\mathrm{mm})\end{array}$ & $\begin{array}{c}\mathrm{MAT}^{\mathrm{c}} \\
\left({ }^{\circ} \mathrm{C}\right)\end{array}$ & $\begin{array}{l}\text { Slope } \\
(\%)\end{array}$ & Vegetation & Microlow Profiles & Classification $^{\mathrm{d}}$ \\
\hline Victoria & 01TX 355-2 & Nueces & $\begin{array}{l}27.56 \\
97.55\end{array}$ & 755 & 22.0 & $0-1$ & Rangeland & A-Bw-Bss-Bssk & $\begin{array}{c}\text { fine, smectitic, hyperthermic } \\
\text { Sodic Haplustert }\end{array}$ \\
\hline Victoria & 01TX 355-1 & Nueces & $\begin{array}{l}27.81 \\
97.72\end{array}$ & 788 & 22.0 & $0-1$ & Rangeland & A-Bw-Bss-Bssk & $\begin{array}{c}\text { fine, smectitic, hyperthermic } \\
\text { Sodic Haplustert }\end{array}$ \\
\hline Victoria & 01TX 409-3 & $\begin{array}{c}\text { San } \\
\text { Patricio }\end{array}$ & $\begin{array}{l}28.11 \\
97.35\end{array}$ & 894 & 22.0 & $0-1$ & Rangeland & A-Bw-Bss-Bssk & $\begin{array}{c}\text { fine, smectitic, hyperthermic } \\
\text { Sodic Haplustert }\end{array}$ \\
\hline Laewest & 99TX 391-1 & Refugio & $\begin{array}{l}28.47 \\
97.12\end{array}$ & 924 & 21.6 & $0-1$ & Rangeland & A-Bss-Bssk & $\begin{array}{c}\text { fine, smectitic, hyperthermic } \\
\text { Typic Hapludert }\end{array}$ \\
\hline Laewest & 99TX 469-1 & Victoria & $\begin{array}{l}28.72 \\
97.76\end{array}$ & 1000 & 21.3 & $0-1$ & Rangeland & A-Bss-Bssk & $\begin{array}{c}\text { fine, smectitic, hyperthermic } \\
\text { Typic Hapludert }\end{array}$ \\
\hline Laewest & 99TX 239-1 & Jackson & $\begin{array}{l}28.88 \\
96.40\end{array}$ & 1066 & 21.1 & $0-1$ & Rangeland & A-Bss-Bssk & $\begin{array}{c}\text { fine, smectitic, hyperthermic } \\
\text { Typic Hapludert }\end{array}$ \\
\hline Lake Charles & 99TX 481-1 & Wharton & $\begin{array}{l}29.43 \\
96.08\end{array}$ & 1124 & 20.3 & $0-1$ & Pasture & Ap-Bss-Bssk & $\begin{array}{c}\text { fine, smectitic, hyperthermic } \\
\text { Typic Hapludert }\end{array}$ \\
\hline Lake Charles & 99TX 157-1 & $\begin{array}{l}\text { Fort } \\
\text { Bend }\end{array}$ & $\begin{array}{l}29.60 \\
95.88\end{array}$ & 1170 & 20.4 & $0-1$ & Pasture & Ap-Bss-Bssk & $\begin{array}{c}\text { fine, smectitic, hyperthermic } \\
\text { Typic Hapludert }\end{array}$ \\
\hline Lake Charles & 99TX 201-1 & Harris & $\begin{array}{l}29.59 \\
95.07\end{array}$ & 1276 & 20.7 & $0-1$ & Rangeland & A-Bss-Bssk & $\begin{array}{c}\text { fine, smectitic, hyperthermic } \\
\text { Typic Hapludert }\end{array}$ \\
\hline League & 001TX 071-1 & Jefferson & $\begin{array}{l}29.80 \\
94.56\end{array}$ & 1331 & 20.3 & $0-1$ & Pasture & Ap-Bssg-Bsskg & $\begin{array}{c}\text { fine, smectitic, hyperthermic } \\
\text { Oxyaquic Dystrudert }\end{array}$ \\
\hline League & $001 \mathrm{TX} 245-2$ & Jefferson & $\begin{array}{l}29.87 \\
94.32\end{array}$ & 1411 & 20.2 & $0-1$ & Pasture & Ap-Bssg-Bsskg & $\begin{array}{c}\text { fine, smectitic, hyperthermic } \\
\text { Oxyaquic Dystrudert }\end{array}$ \\
\hline League & 001TX 245-1 & Jefferson & $\begin{array}{l}30.04 \\
94.19\end{array}$ & 1437 & 20.2 & $0-1$ & Pasture & Ap-Bssg-Bsskg & $\begin{array}{c}\text { fine, smectitic, hyperthermic } \\
\text { Oxyaquic Dystrudert }\end{array}$ \\
\hline
\end{tabular}

a See Fig. 1 for pedon localities.

b Pedon data taken from Soil Survey Staff, 2008 (http://ssldata.nrcs.usda.gov).

c Rainfall and temperature data taken from http://www.worldclimate.com/ (1961-1990).

d See Soil Survey Staff, 1999.

$1250 \mathrm{~mm}$ of MAP. All subsoils at varying depths are alkaline (Nordt et al., 2006). In sum, the Victoria series is classified as Sodic Haplusterts, the Laewest and Lake Charles as Typic Hapluderts, and the League as Oxyaquic Dystruderts. All classify as fine, smectitic, hyperthermic at the Family taxonomic level.

Each of the twelve soil pits was excavated with a backhoe to dimensions of 4 to $6 \mathrm{~m}$ long, $2 \mathrm{~m}$ wide, and 2 to $4 \mathrm{~m}$ deep. Close-range spatial variability of microlows and microhighs exhibits gilgai surface relief of 10 to $30 \mathrm{~cm}$. The distance between microhighs is typically 2 to $3 \mathrm{~m}$, which also tracks the degree of subsurface waviness (see Fig. 2a, b). In each pit, all horizons from a microlow and microhigh pedon were described and sampled according to standard procedures (Soil Survey Division Staff, 1993). Each sampled horizon was characterized for routine physical and chemical properties at the Soil Survey Laboratory in Lincoln, Nebraska (Soil Survey Staff, 1994; USDA-NRCS, 1995; http://ssldata.nrcs.usda.gov).

For this investigation, we assessed field morphological and laboratory data related to wetness across the climosequence. From field descriptions we extracted morphological information of redoximorphic features in the form of iron concentrations (concretions, soft masses, pore linings) and iron de- pletions (soft masses and pores) in relation to matrix colors. The compiled information included abundance (\%), location (matrix versus void wall), diameter (fine, medium, coarse), color (Munsell chart), and boundary (diffuse versus nondiffuse). In terms of boundary we combined clear and sharp into the category of nondiffuse, to differentiate from diffuse. Features with clear and sharp boundaries are gradational over a distance of $<2 \mathrm{~mm}$ whereas diffuse boundaries are gradational over a distance of $>2 \mathrm{~mm}$ (Schoeneberger, 2002). Boundary is important because contemporaneous redoximorphic features in growth stages tend to have diffuse boundaries with relict features having nondiffuse boundaries (Vepraskas, 2001). Another point of clarification is that iron depletions have either gray or gleyed colors. The former has chromas of $\leq 2$ and values of $\geq 4$ with the assumption that they represent contemporaneous loss of iron from saturated and reduced conditions. These gray colors, however, can be inherited from the parent material or from a former soil moisture regime (Vepraskas, 2001). In contrast, gleyed colors, found on the gleyed Munsell color pages, are thought to reflect the contemporaneous accumulation of ferrous iron (Vepraskas, 2001). If the redoximorphic field descriptions were incomplete, these horizons were eliminated from the data compilation. 

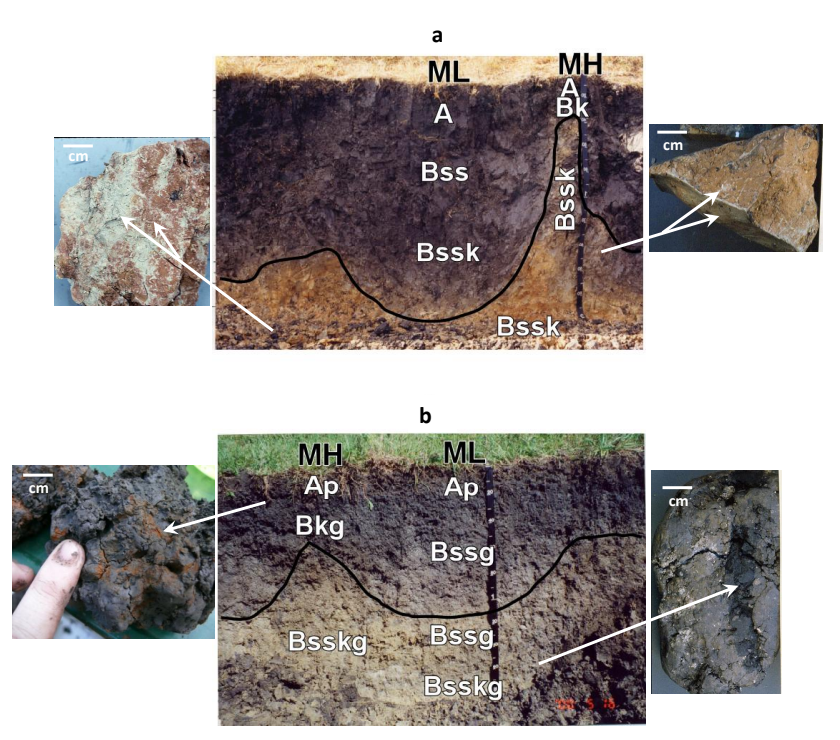

Fig. 2. Field pit photos of a (a) Laewest soil (LAW 99TX 469-1) and (b) League soil (LEG 00TX 245-1) in the study area exhibiting microlow and microhigh topography, genetic horizonation, and examples of redoximorphic features. Both profiles are approximately $2 \mathrm{~m}$ deep. Right panel of the Laewest soil shows a wedge-shaped aggregate with iron depleted face and iron depleted pores. Left panel of the Laewest soil is an example of an iron depleted mass and associated soft iron mass from the lower profile. Right panel of the League soil shows a crayfish burrow and the left panel iron pore linings from the surface horizon.

Dithionite-citrate extractable $\left(\mathrm{Fe}_{d}\right)$ and ammoniumoxalate extractable $\left(\mathrm{Fe}_{o}\right)$ iron oxides were evaluated from the characterization data because these iron species are pedogenic and the principal contributor to the formation of redoximorphic features. These chemical data were cross-checked with matrix colors and abundance of redoximorphic features described in the profiles. Additionally, crayfish burrows were documented with regard to location and depth as a marker for wetness conditions. The entirety of the characterization data were used to help taxonomically classify the Vertisols.

For methods describing water table monitoring for the two localities in the study area, see Griffin (1991). It is important to note that whereas the Griffin (1991) study defines saturation as water that can be measured in a piezometer, others believe that it is best described as "free water" because of the ease of saturating macrovoids and the difficulty of completely saturating ped interiors in Vertisols (Wes Miller, personal communication, 2009).

\section{Matrix colors}

Matrix colors of surface horizons meet the requirements of a mollic epipedon (Soil Survey Staff, 1999) in most microlows and microhighs across the climosequence, reflecting the importance of below-ground biomass production from the as-

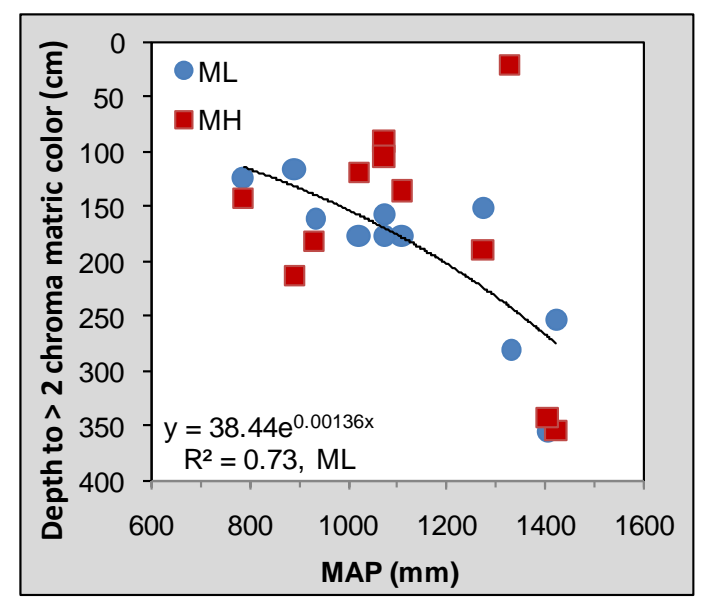

Fig. 3. Depth to $>2$ chroma matrix colors by microlow and microhigh.

sociated grassland community. When the thickness requirement is not met, it is by only a few $\mathrm{cm}$, in part an artifact of profile selection within each of the pit excavations. There is a wide range of color hues of B horizons in the study area, even though gray matrixes (value $\geq 4$, chroma $\leq 2$ ) dominate the profiles in the upper $1 \mathrm{~m}$. The depths at which chromas of $>2$ are first encountered increases with increasing rainfall in both the microlow and microhigh (Fig. 3). There is a strong correlation in the microlow between depth to $>2$ chroma and MAP, with the microhigh exhibiting a similar relationship except for one outlier that presumably is a by-product of shrinkswell forces and lateral and vertical shifting of soil materials.

\section{Redoximorphic features}

\subsection{Iron concentrations}

Visible forms of iron manganese segregations in the study area exists largely as concretions with abrupt boundaries, and show no relationship to climate in terms of abundance, depth, size, or color. This suggests that these redoximorphic features are relict and not actively forming today (Vepraskas, 2001). A few ped coats and pore linings deep in some profiles indicate periodic reduction and precipitation of iron manganese in localized settings.

In microlows, soft iron masses with nondiffuse boundaries first occur at $\sim 924 \mathrm{~mm}$ of MAP and for those with diffuse boundaries at $\sim 1066 \mathrm{~mm}$ (Fig. $4 \mathrm{a}$ ). These redoximorphicrainfall relationships generally hold for the microhighs except for soft iron masses with diffuse boundaries not occurring until $1276 \mathrm{~mm}$ of MAP (Fig. 4b). Further, the proportion of the solum $(\mathrm{cm})$ containing soft iron masses increases in the both the microlow and microhigh with increasing rainfall, although there is considerable variability to this trend (Fig. 4a, b). These data also indicate that soft iron masses in the 

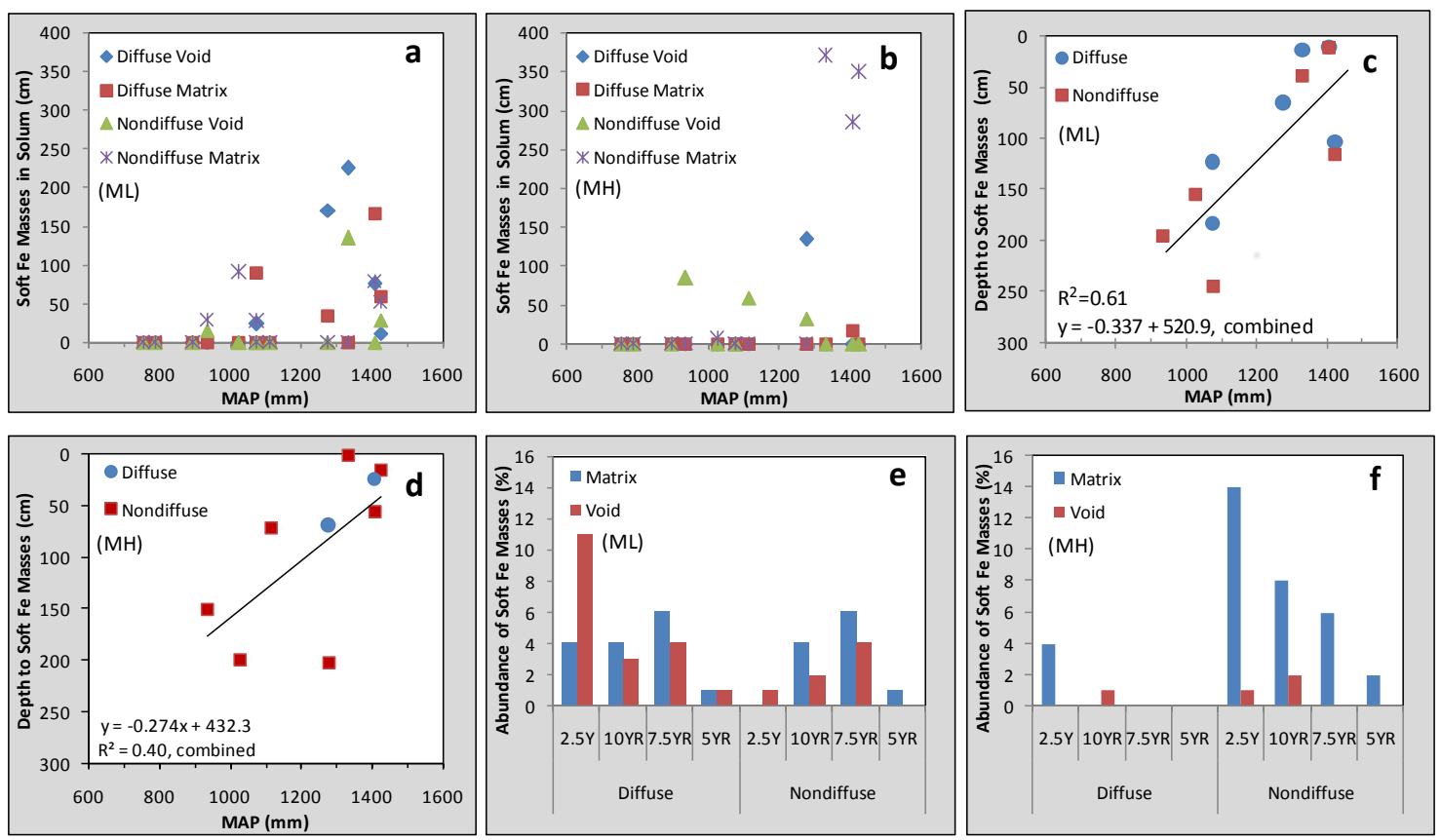

Fig. 4. Proportion of solum containing soft iron masses with diffuse and nondiffuse boundaries in relation to matrix and voids by microlow (a) and microhigh (b); depth to first soft iron masses with diffuse and nondiffuse boundaries by microlow (c) and microhigh (d); and abundance of color hues of soft iron masses with diffuse and nondiffuse boundaries in relation to matrix and voids by microlow (e) and microhigh (f).

microlow are of equal importance in terms of boundary (diffuse versus nondiffuse) and location (void versus matrix). In microhighs, however, nearly all of the soft iron masses have nondiffuse boundaries, but as with microlows, they occur in either the matrix or along voids. The depth to the first soft iron masses, whether with diffuse or nondiffuse boundaries, systematically decreases with increasing rainfall in both the microlow and microhigh (Fig. 4c, d). Once encountered, the presence of soft iron masses generally persists to the bottom of the solum in both topographic positions. Color hues of soft iron masses in the microlows neither relate to rainfall, nor to whether the boundaries of the masses are diffuse or nondiffuse, nor to whether they occur in the matrix or along voids (Fig. 4e). There is no correlation of these properties to rainfall in the microhighs either, even though most soft iron masses have nondiffuse boundaries in the matrix (Fig. 4f).

Iron pore linings become visible in surface horizons of both microlows and microhighs at $1276 \mathrm{~mm}$ of MAP, but across a greater thickness of the profile in the microlows (Fig. 5a). All iron pore linings have a relatively uniform distribution of diffuse and nondiffuse boundaries in microlows, but with nondiffuse boundaries dominantly occurring in microhighs (Fig. 5b). Color hues show little preference to any particular pore lining regardless of boundary, and range from $2.5 \mathrm{Y}$ to $5 \mathrm{YR}$.

\subsection{Iron depletions}

Iron-depleted soft masses do not appear until $\sim 1000 \mathrm{~mm}$ of MAP in microlows where they are exclusively along voids, but with either diffuse or nondiffuse boundaries (Fig. 6a). In microhighs, depleted soft iron masses first appear near $1066 \mathrm{~mm}$ of MAP and are dominated by nondiffuse boundaries that occur equally between the matrix and voids (Fig. 6b). In terms of depth to iron-depleted masses and pores, there is no correlation to MAP in either the microlow or microhigh (Fig. 6c, d). Regardless of boundary condition, depleted masses in microlows have equal proportions of gleyed and gray colors (Fig. 6e). In microhighs, the few nondiffuse boundaries that occur are all gray and along voids (Fig. 6f). However, depleted masses with nondiffuse boundaries are somewhat equally represented between gleyed and gray and between voids and the matrix.

Iron-depleted pores dominate the microlows, and as with depleted soft masses, are first identified at $1000 \mathrm{~mm}$ of MAP, and shortly thereafter in microhighs (Fig. 7a). They increase somewhat in abundance as rainfall increases. Depleted pores have both gleyed and gray colors and both diffuse and nondiffuse boundaries in microlows (Fig. 7b). All depleted pores in microhighs have nondiffuse boundaries, but are all gleyed.

\subsection{Crayfish burrows}

We classify crayfish burrows (krotovina) as a redoximorphic feature because these fauna require water-logged habitats. 

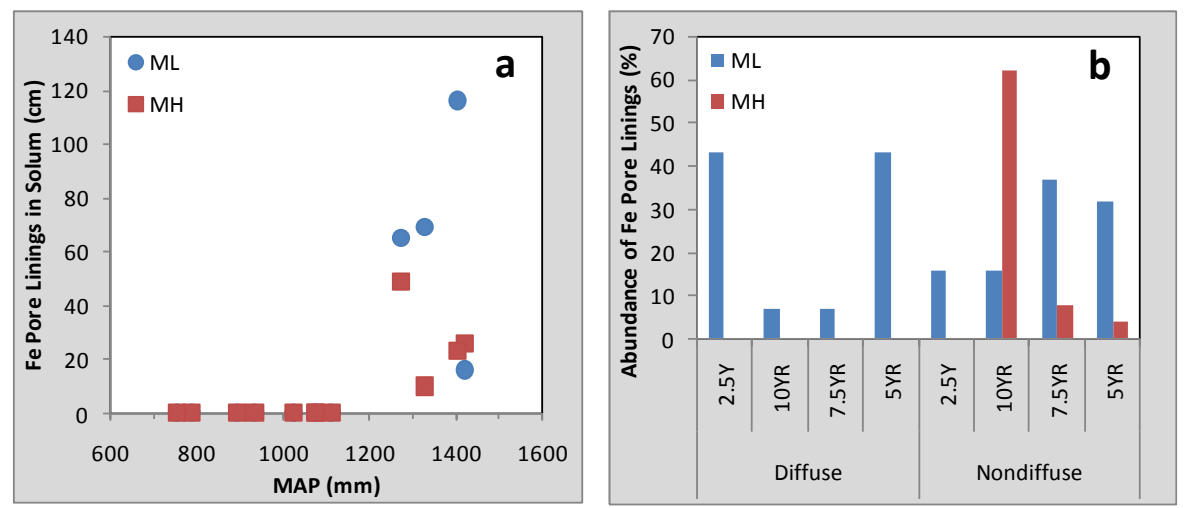

Fig. 5. Proportion of solum containing iron pore linings (a) and abundance of color hue with diffuse and nondiffuse boundaries (b) by microlow and microhigh.
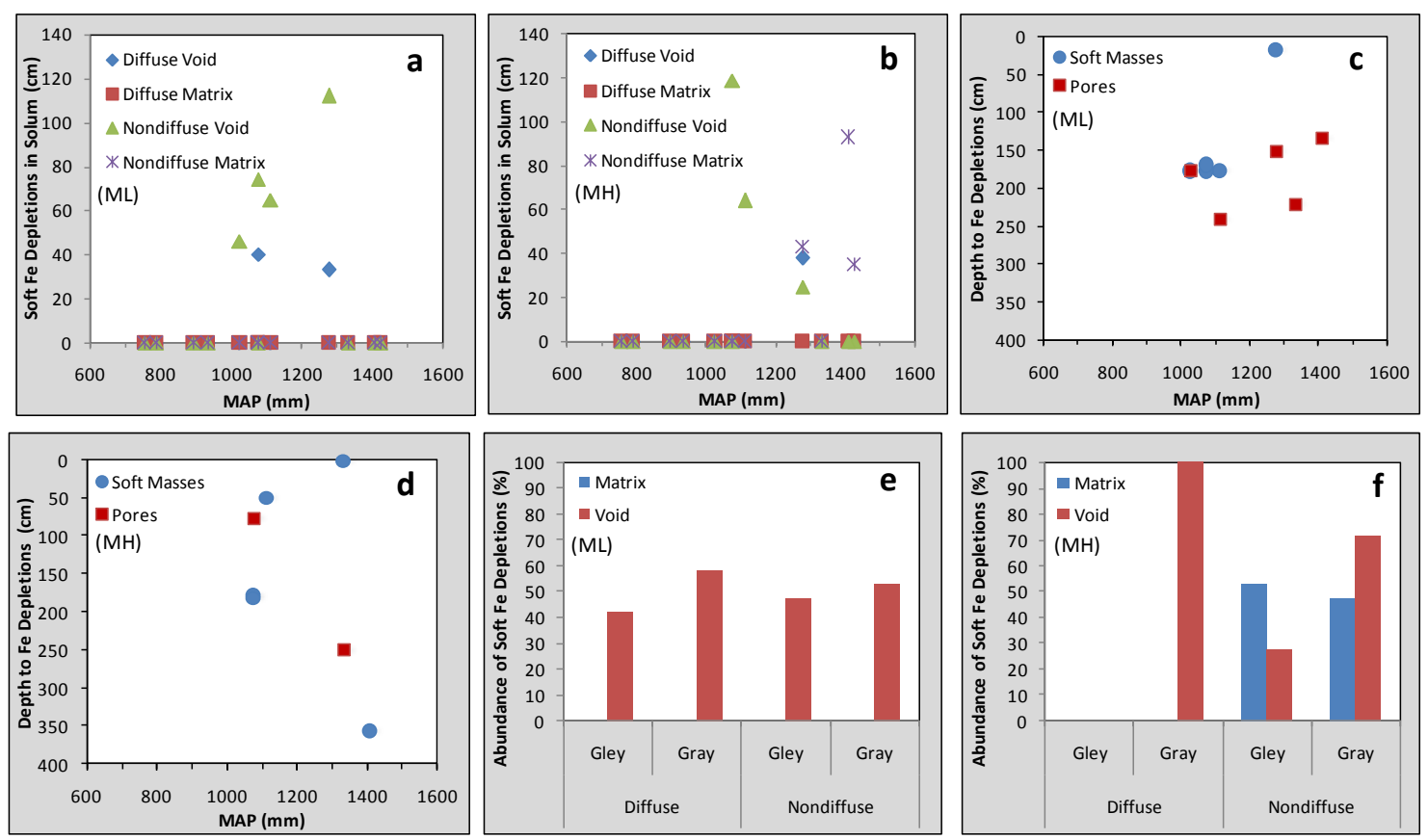

Fig. 6. Proportion of solum containing soft iron depletions with diffuse and nondiffuse boundaries in relation to matrix and voids by microlow (a) and microhigh (b); depth to first iron-depleted soft masses and pores by microlow (c) and microhigh (d); and abundance of color hue of soft iron masses with diffuse and nondiffuse boundary in relation to matrix and voids by microlow (e) and microhigh (f).

The crayfish in our study area are probably those with complex burrows beginning near the ground surface above the water table and that branch downward to the water table, consistent with seasonally wet soils (Hasiotis and Mitchell, 1993; Stone, 1993). In our climosequence on shallow, linear slopes, crayfish burrows do not appear until MAP $1066 \mathrm{~mm}$ (Fig. 8), which roughly coincides with the ustic/udic soil moisture regime boundary and the first appearance of iron redoximorphic features. Notably, there is a strong correlation between the depth of these features and MAP as the burrows approach the surface with greater rainfall. Crayfish burrows do not appear in microhighs until approximately $1400 \mathrm{~mm}$ of MAP, however.

The length and thickness of individual crayfish burrows reveal no particular pattern along the climosequence. Further, the material used to line the walls of the burrows appears to reflect derivation from local soil material, typically consisting of an array of red, gray, brown and yellow colors. Even with prolonged saturation, the colors of the lined walls exhibit variegated colors probably because individual burrows do not persist long enough for sufficient iron reduction to form dominantly gray colors. 

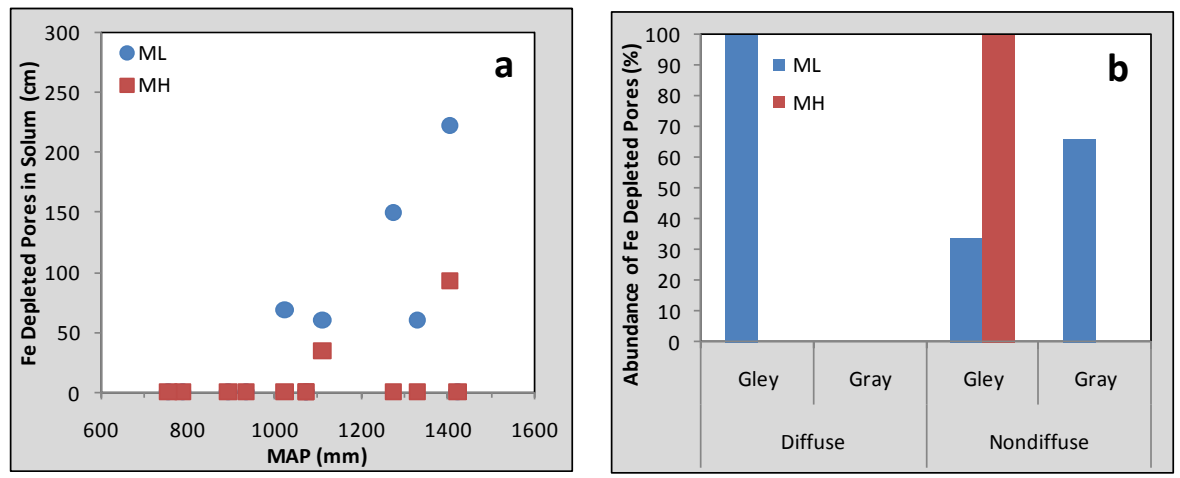

Fig. 7. Proportion of solum containing iron depleted pores (a) and abundance of gleyed and gray color hues with diffuse and nondiffuse boundaries (b) by microlow and microhigh.

\section{4 $\mathrm{Fe}_{o}$ and $\mathrm{Fe}_{d}$}

The quantity of extractable $\mathrm{Fe}_{d}$ and $\mathrm{Fe}_{o}$ iron oxides in the surface horizons of the climosequence increases systematically with rainfall in both microlows and microhighs (Fig. 9a, b). Quantities of both oxides in microlows and microhighs of surface horizons are nearly identical, confirming field observations of similar matrix colors and abundances of iron oxide features (compare to Fig. 4). The difference is that a greater proportion of these features may be relict in the microhighs because of their nondiffuse boundaries.

We also plotted $\mathrm{Fe}_{d}$ and $\mathrm{Fe}_{o}$ data at a depth of $100 \mathrm{~cm}$ and discovered a similar trend with $\mathrm{Fe}_{d}$ as in the surface horizon, but that the overall concentration of $\mathrm{Fe}_{o}$ decreases as it forms a curvilinear trend with increasing rainfall (Fig. 9c, d). The $\mathrm{Fe}_{o}$ trend is both subtle and difficult to explain, however, and may be related to localized, rather than regional, climate conditions.

\section{Comparison of redoximorphic features to monitoring stations}

We compared our field and laboratory biweekly observations to two other Vertisols in the study area that had been hydromorphically monitored from September, 1989 through December, 1990 (Griffin, 1991). The first of these pedons was described and sampled as the Beaumont series (88TX 2451), which was later correlated to the League series. The other was described and sampled as the Lake Charles Series (88TX 469-1), but later correlated to the Laewest series. Saturation was measured with piezometers (depths of $25,50,100$, and $200 \mathrm{~cm}$ ) and tensiometers (depths of 25 , 50 , and $100 \mathrm{~cm}$ ) with iron reduction determined with alpha, alpha'-dipyridil (depths of $0,25,50$, and $100 \mathrm{~cm}$ ). The Laewest monitoring station (microlow) in Victoria County near the city of Victoria, Texas receives $\sim 950 \mathrm{~mm}$ of MAP and is compared to morphological and chemical data from

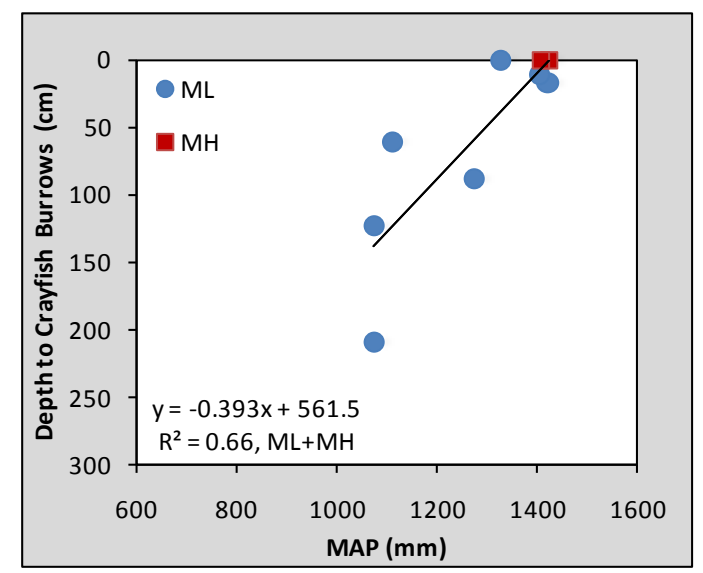

Fig. 8. Depth to first crayfish burrows by microlows and microhighs.

our nearby Laewest (99TX 469-1) pedon from the same area (Fig. 1; Table 1; Fig. 2a). The monitoring site has never been cultivated and is in native rangeland. During the monitoring period average rainfall slightly exceeded the 30-year mean. The League monitoring station (transitional microlow to microhigh) in Jefferson County near the city of Beaumont, Texas was compared to results of our nearby League (00TX 245-1) pedon from the same area (Fig. 1; Table 1; Fig. 2b). The Jefferson County site was under cultivation, but not irrigated. Its MAP is $\sim 1400 \mathrm{~mm}$ with the average during the monitoring period slightly exceeding the 30 -year mean.

At the Laewest site the interval of saturation during the monitoring period increased from 5\% at the surface to $31 \%$ at a depth of $100 \mathrm{~cm}$ according to piezometers, but in the absence of iron reduction as measured by alpha, alpha'dipyridil except for one brief interval in the surface horizon (Fig. 10a). Tensiometers exhibit somewhat less saturation at depth than do piezometers, perhaps indicating that ped 

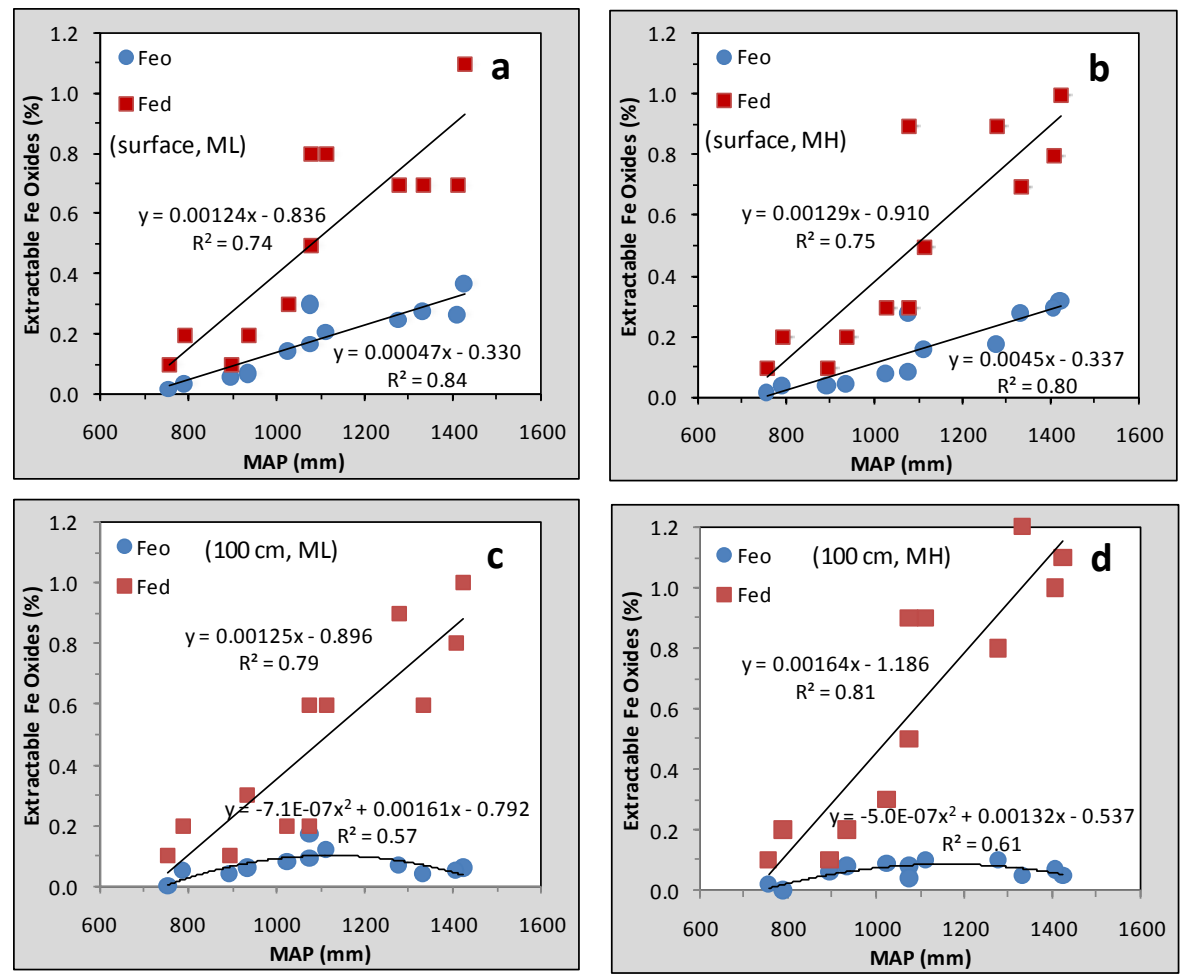

Fig. 9. Weight percentage of $\mathrm{Fe}_{d}$ and $\mathrm{Fe}_{o}$ extractable iron oxides for surface horizon by microlow (a) and microhigh (b) and at a depth of $100 \mathrm{~cm}$ by microlow (c) and microhigh $(\mathbf{d})$.

interiors take longer to wet. At both the monitoring station and in our study area neither soft iron masses nor pore linings were described within the upper $100 \mathrm{~cm}$ (Table 2), consistent with the absence of chemically-detected reduced iron. This is supported by data showing that the most kinetically active forms of iron, as measured by $\mathrm{Fe}_{o}$, are low within this depth interval (see Fig. 9). Thus, whereas this soil is saturated for up to $31 \%$ of the time within the upper $100 \mathrm{~cm}$, it is an expression of oxyaquic rather than aquic conditions.

Even though the surface was never saturated during the monitoring period for the League soil according to piezometers, it differs from the Laewest because saturation increases from $29 \%$ of the monitoring period at a depth of $25 \mathrm{~cm}$ to nearly $100 \%$ of the monitoring period at a depth of $100 \mathrm{~cm}$ (Fig. 10b). Iron reduction occurred at the surface for approximately $25 \%$ of the monitoring period before decreasing to $2 \%$ at depths of 25 and $50 \mathrm{~cm}$, followed by an increase to $8 \%$ at a depth of $100 \mathrm{~cm}$. However, only $8 \%$ of the time was the entire soil mass reduced according to alpha, alpha'-dipyridil in the surface horizons (data not shown) that according to Griffin (1991) is related to microsites with elevated levels of organic matter and microbial activity. Griffin (1991) also described few to common soft iron masses throughout the upper $100 \mathrm{~cm}$ of the monitored League soil. Our observations of League (LEG 00TX 245-1) revealed $9 \%$ iron pore linings in the surface horizon with few to common soft iron masses beginning at a depth of $\sim 100 \mathrm{~cm}$ and extending to the bottom of the profile (Table 2). The presence of these features with diffuse boundaries confirms significant intervals of contemporaneous iron reduction.

\section{Taxonomic and hydric classification}

Aquic conditions occur with coincidence of saturation and reduction in the presence of iron redoximorphic features. According to the USDA Soil Taxonomy (Soil Survey Staff, 1999), aquic conditions at the suborder level of Vertisols must occur within a depth of $50 \mathrm{~cm}$ for an unspecified period. For the subgroup level, aquic conditions must occur within the upper $100 \mathrm{~cm}$. Oxyaquic conditions, or saturation without reduction, must occur throughout the upper $100 \mathrm{~cm}$ for 20 days consecutively or 30 days cumulatively during an annual cycle. Oxyaquic conditions can only be inferred from water table monitoring data, whereas aquic conditions can be inferred from field observations of redoximorphic features.

A summary of our field morphological observations of redoximorphic features offers a starting point for interpretations of the taxonomic classification of soil moisture regimes across the climosequence (Fig. 11). In microlows, low chroma matrix colors persist within a depth of $50 \mathrm{~cm}$ in both the ustic and udic soil moisture regimes, making it an 
Table 2. Key properties of a typical Laewest (LAW) and League (LEG) pedon in the study area (see Figs. 1, 2).

\begin{tabular}{|c|c|c|c|c|c|c|c|c|c|c|c|c|c|c|c|c|c|c|}
\hline \multirow[t]{3}{*}{ Pedon } & \multirow[t]{3}{*}{ Horizon } & \multirow{3}{*}{$\begin{array}{l}\text { Depth } \\
(\mathrm{cm})\end{array}$} & \multirow{3}{*}{$\begin{array}{l}\text { SOC } \\
(\%)\end{array}$} & \multirow{3}{*}{$\begin{array}{r}\mathrm{pH} \\
\left(\mathrm{H}_{2} \mathrm{O}\right)\end{array}$} & \multicolumn{4}{|c|}{ Macrovoids } & \multirow[t]{3}{*}{ Matrix } & \multicolumn{9}{|c|}{ Redoximorphic Features $^{\mathrm{d}}$} \\
\hline & & & & & \multirow[t]{2}{*}{ Structure $^{\mathrm{a}}$} & \multirow[t]{2}{*}{ Slicks ${ }^{\mathrm{b}}$} & \multirow[t]{2}{*}{ Roots $^{c}$} & \multirow{2}{*}{$\begin{array}{r}\text { Crayfish } \\
(\%)\end{array}$} & & \multicolumn{4}{|c|}{ Iron Concentrations } & \multicolumn{4}{|c|}{ Iron Depletions } & \multirow{2}{*}{$\begin{array}{l}\mathrm{Fe}_{o}^{\mathrm{e}} \\
(\%)\end{array}$} \\
\hline & & & & & & & & & & $(\%)$ & Loc & Bound & Color & $(\%)$ & Loc & Bound & Color & \\
\hline \multirow{13}{*}{$\begin{array}{l}\overline{1} \\
\text { ò } \\
+ \\
\vdots \\
3\end{array}$} & & & & & & & & Microlow & & & & & & & & & & \\
\hline & A & $0-16$ & 1.89 & 6.1 & $\mathrm{~m} 1 \mathrm{sbk}$ & 0 & c1 & 0 & 10YR 2/1 & 0 & - & - & - & 0 & - & - & - & 0.15 \\
\hline & Bss1 & $16-43$ & 1.26 & 6.5 & $\mathrm{~m} 2 \mathrm{sbk}$ & $\mathrm{cd}$ & c1 & 0 & 10YR 2/1 & 0 & - & - & - & 0 & - & - & - & 0.11 \\
\hline & Bss2 & $43-118$ & 1.18 & 7.1 & m2abk & $\mathrm{mp}$ & $\mathrm{cl}$ & 0 & $10 \mathrm{YR} 2 / / 1$ & 0 & - & - & - & 0 & - & - & - & 0.08 \\
\hline & Bssk1 & $118-176$ & 0.44 & 7.9 & m2we-abk & $\mathrm{mp}$ & $\mathrm{c} 1$ & 0 & 10YR 3-4/1 & 1 & $\mathrm{~m}$ & $\mathrm{n}$ & 7.5YR & 0 & - & - & - & 0.06 \\
\hline & Bssk2 & $176-245$ & 0.26 & 8.0 & m2-3abk & md & c1 & 0 & 10YR 6/6 & 1 & $\mathrm{~m}$ & $\mathrm{n}$ & $7.5 \mathrm{YR}$ & 1 & $\mathrm{v}$ & $\mathrm{n}$ & $2.5 \mathrm{Y}$ & 0.06 \\
\hline & Bss & $245-265$ & 0.34 & 8.0 & m2-3abk & $\mathrm{md}$ & $\mathrm{fl}$ & 0 & 10YR $7 / 6$ & 2 & $\mathrm{p}$ & $\mathrm{n}$ & $5 \mathrm{YR}$ & 0 & - & - & - & 0.05 \\
\hline & & & & & & & & Microhigh & & & & & & & & & & \\
\hline & A & $0-11$ & 1.39 & 8.1 & $\mathrm{~m} 2 \mathrm{sbk}$ & 0 & $\mathrm{c} 1$ & 0 & 10YR 4/1 & 0 & - & - & - & 0 & - & - & - & 0.08 \\
\hline & $\mathrm{Bk}$ & $11-28$ & 0.34 & 8.1 & m2abk & 0 & $\mathrm{c} 1$ & 0 & $2.5 \mathrm{Y} 4 / 2$ & 0 & - & - & - & 0 & - & - & - & 0.09 \\
\hline & Bssk1 & $28-119$ & 0.59 & 8.3 & m2we & md & f1 & 0 & $2.5 Y 5 / 2$ & 0 & - & - & - & 0 & - & - & - & 0.09 \\
\hline & Bssk2 & 119-198 & 0.04 & 8.4 & m3we & $\mathrm{md}$ & f1 & 0 & $2.5 Y 5 / 3-4$ & 0 & - & - & - & 0 & - & - & - & 0.08 \\
\hline & Bss & $198-265$ & 0.12 & 8.2 & m3abk & md & f1 & 0 & 10YR 6-7/6 & 2 & $m-p$ & $\mathrm{n}$ & 5-7.5YR & 0 & - & - & - & 0.08 \\
\hline \multirow{18}{*}{ 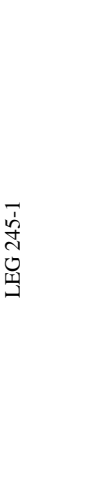 } & & & & & & & & Microlow & & & & & & & & & & \\
\hline & Ap & $0-16$ & 2.80 & 6.4 & w1sbk & 0 & c1 & 0 & $2.5 \mathrm{Y} 3 / 1$ & 9 & $\mathrm{p}$ & $\mathrm{d}$ & $2.5 \mathrm{Y} / 5 \mathrm{YR}$ & 0 & - & - & - & 0.37 \\
\hline & Bssg1 & $16-72$ & 1.21 & 7.3 & m2sbk-we & md & c1 & 1.5 & $2.5 \mathrm{Y} 3 / 1$ & 0 & - & - & - & 0 & - & - & - & 0.13 \\
\hline & Bssg2 & $72-115$ & 0.76 & 7.9 & w2we-abk & $\mathrm{mp}$ & f1 & 2 & 10YR 4.5/1 & 0 & - & - & - & 0 & - & - & - & 0.06 \\
\hline & Bssg3 & $115-156$ & 0.32 & 8.1 & m3we-abk & $\mathrm{md}$ & f1 & 1 & 10YR 5/1 & 18 & $\mathrm{~m}-\mathrm{p}$ & n-d & $10 \mathrm{YR}$ & 0 & - & - & - & 0.04 \\
\hline & Bssg3 & $156-223$ & 0.11 & 8.3 & w3we-abk & md & $\mathrm{fl}$ & 1 & 10YR 6/1 & 10 & $\mathrm{~m}$ & $\mathrm{~d}$ & $10 \mathrm{YR}$ & 0 & - & - & - & 0.05 \\
\hline & Bssg4 & $223-252$ & 0.08 & 8.4 & m3we-abk & $\mathrm{md}$ & $\mathrm{fl}$ & 1 & 10YR 7/1 & 1 & $\mathrm{~m}$ & $\mathrm{n}$ & $7.5 \mathrm{YR}$ & 0 & - & - & - & 0.14 \\
\hline & Bsskg & $252-275$ & 0.15 & 8.3 & m3we-abk & md & $\mathrm{f} 1$ & 1 & 7.5YR 5/6 & 1 & $\mathrm{~m}$ & $\mathrm{n}$ & 7.5YR & 0 & - & - & - & 0.09 \\
\hline & & & & & & & & Microhigh & & & & & & & & & & \\
\hline & Ap & $0-15$ & 2.86 & 6.7 & w2sbk & 0 & $\mathrm{cl}$ & 0 & $2.5 \mathrm{Y} 3 / 1$ & 4 & $\mathrm{p}$ & $\mathrm{n}$ & $7.5 \mathrm{YR}$ & 0 & - & - & - & 0.32 \\
\hline & A & $15-26$ & 1.14 & 7.9 & w2sbk & 0 & c1 & 5 & $2.5 \mathrm{Y} 3 / 1$ & 20 & $\mathrm{~m}$ & $\mathrm{n}$ & $2.5 \mathrm{Y}$ & 0 & - & - & - & 0.19 \\
\hline & $\mathrm{Bkg}$ & $26-46$ & 0.75 & 8.2 & m2abk & 0 & c1 & 5 & $2.5 \mathrm{Y} 5 / 2$ & 9 & $\mathrm{~m} / \mathrm{p}$ & $\mathrm{n}$ & $7.5 \mathrm{YR}$ & 0 & - & - & - & 0.09 \\
\hline & Bssg1 & $46-67$ & 0.41 & 8.1 & $\mathrm{~m} 2 \mathrm{we}-\mathrm{abk}$ & md & $\mathrm{fl}$ & 5 & $2.5 \mathrm{Y} 5 / 2$ & 20 & $\mathrm{~m}$ & $\mathrm{n}$ & $2.5 \mathrm{Y}$ & 0 & - & - & - & 0.07 \\
\hline & Bssg2 & $67-120$ & 0.40 & 8.1 & $\mathrm{~m} 2 \mathrm{we}-\mathrm{abk}$ & $\mathrm{cp}$ & f1 & 5 & $2.5 \mathrm{Y} 4 / 1$ & 22 & $\mathrm{~m}$ & $\mathrm{n}$ & $10 \mathrm{YR}-2.5 \mathrm{Y}$ & 0 & - & - & - & 0.06 \\
\hline & Bssg3 & $120-154$ & 0.36 & 8.1 & m3we-abk & $\mathrm{cp}$ & $\mathrm{fl}$ & 10 & $2.5 Y 5 / 1$ & 22 & $\mathrm{~m}$ & $\mathrm{n}$ & $2.5 \mathrm{Y}$ & 0 & - & - & - & 0.04 \\
\hline & Bsskg1 & $154-195$ & 0.00 & 8.4 & m3we-abk & $\mathrm{cp}$ & $\mathrm{fl}$ & 5 & $2.5 Y 5 / 1$ & 20 & $\mathrm{~m}$ & $\mathrm{n}$ & $2.5 \mathrm{Y}$ & 0 & - & - & - & 0.05 \\
\hline & Bsskg2 & $195-270$ & 0.00 & 8.4 & w3we-abk & $\mathrm{cp}$ & f1 & 7 & $2.5 \mathrm{Y} 7 / 1$ & 11 & $\mathrm{~m}$ & $\mathrm{n}$ & 7.5YR & 0 & - & - & - & 0.08 \\
\hline & Bss & $355-370$ & 0.00 & 8.2 & m3abk & $\mathrm{fd}$ & - & 3 & 7.5 YR 4/6 & 10 & $\mathrm{~m}$ & $\mathrm{n}$ & $5 \mathrm{YR}$ & 50 & $\mathrm{~m}-\mathrm{v}$ & $\mathrm{n}$ & $2.5 \mathrm{Y}$ & 0.07 \\
\hline
\end{tabular}

a Structure - w=weak, $\mathrm{m}=$ moderate; $1=$ =fine, 2=medium, 3=coarse; sbk=subangular blocky, abk=angular blocky, we-wedge.

b Slickensides $-\mathrm{f}=$ few, $\mathrm{c}=$ common, $\mathrm{m}=$ many; $\mathrm{d}=$ distinct, $\mathrm{p}=$ prominent.

c Roots $-\mathrm{f}=$ few, $\mathrm{c}=$ common; $1=$ fine.

$\mathrm{d}$ Redoximorphic properties $-\mathrm{m}=$ matrix, $\mathrm{v}=$ void, $\mathrm{p}=$ pore (location); $\mathrm{n}=$ =nondiffuse, $\mathrm{d}=$ diffuse (boundary).

e $\mathrm{Fe}_{o}$ - ammonium-oxalate extractable iron oxide.
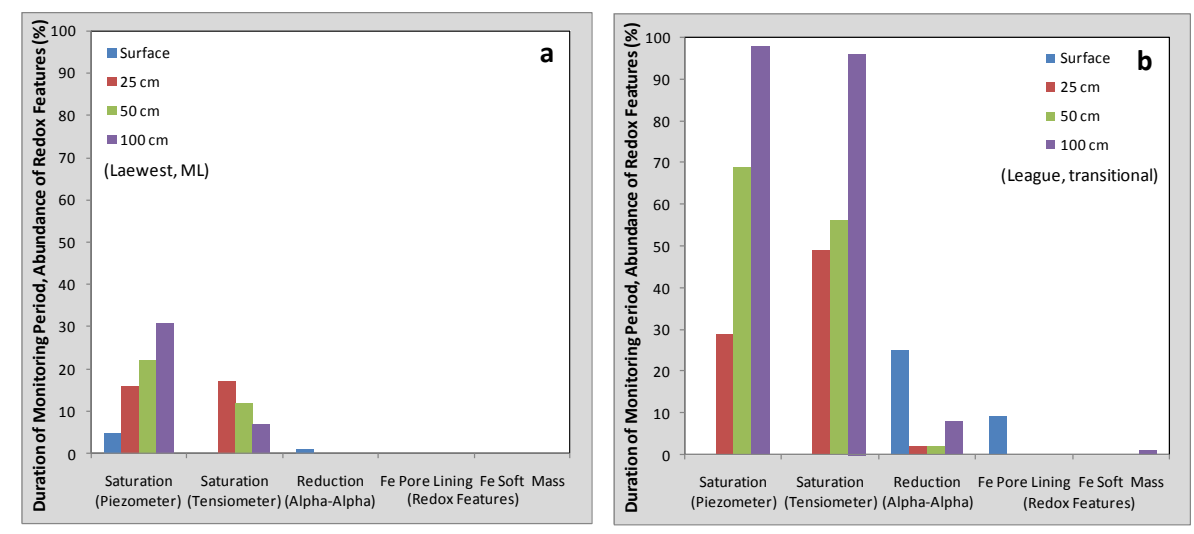

Fig. 10. Water table monitoring data (piezometer and tensiometer for saturation, and alpha alpha'-dipyridil for iron reduction) from a microlow of a nearby Laewest (a) and League (b) soil (Griffin,1991), in comparison to redoximorphic features (iron pore linings and soft masses) from a microlow of one of our Laewest (LAW 99TX 469-1) soils (a) and from a transitional microtopographic position of a League (LEG 00TX 245-1) soil (b) soil from the study area (Fig. 1). 

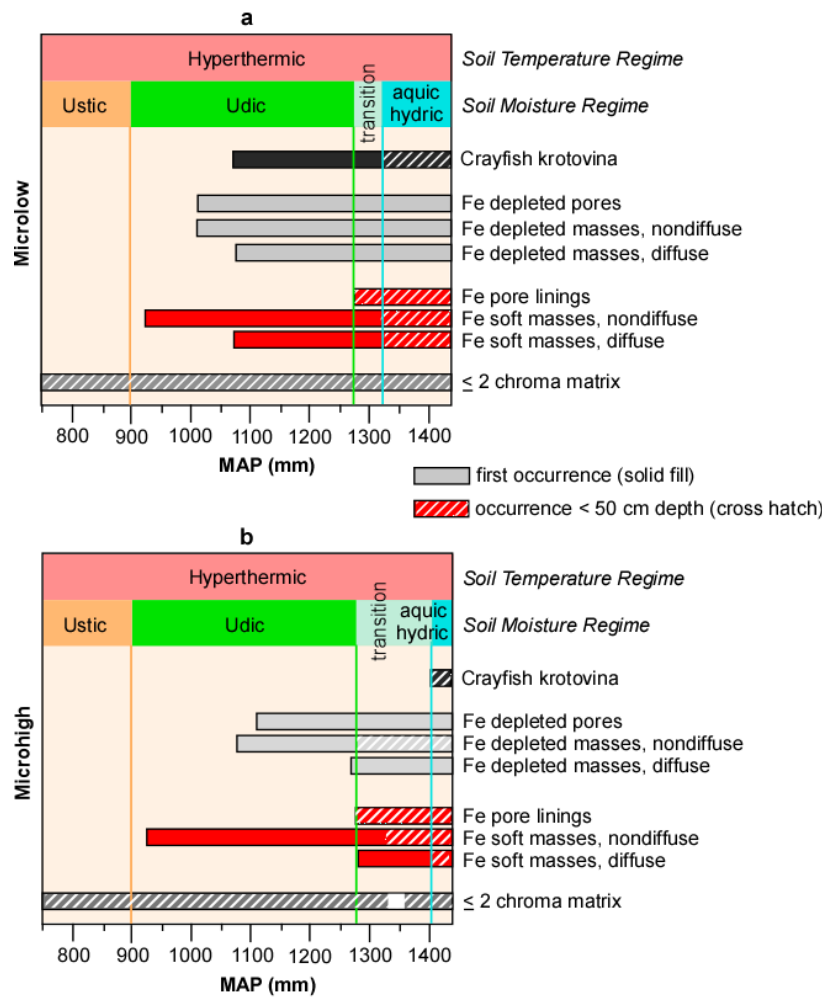

Fig. 11. Summary field observations of redoximorphic features pertinent to taxonomic classification of aquic soil moisture regimes across the Vertisol climosequence.

insensitive indicator of rainfall and wetness conditions. Iron concentrations with nondiffuse boundaries first appear, and below a depth of $50 \mathrm{~cm}$, near $924 \mathrm{~mm}$ of MAP and those with diffuse boundaries near $1066 \mathrm{~mm}$ of MAP. As MAP approaches $1276 \mathrm{~mm}$, iron concentrations begin to form within the upper $50 \mathrm{~cm}$ of the profiles, however; iron depletions do not occur anywhere within the upper $50 \mathrm{~cm}$ in the entire study area. In microlows, the first appearance and depth to crayfish burrows is similar to iron concentrations, providing a powerful accessory property to wetness conditions. Assuming that low chroma matrixes are at least in part the result of contemporaneous iron reduction and mobilization, the presence and abundance of iron pore linings and soft iron masses, whether with diffuse or nondiffuse boundaries, support placement of the aquic soil moisture regime boundary to between $\sim 1276$ and 1331 mm of MAP. Another observation is that the $\mathrm{Fe}_{o} / \mathrm{Fe}_{d}$ ratio at this boundary shows that of the total pedogenic iron oxide in the surface horizons, $31 \%$ is comprised of $\mathrm{Fe}_{o}$. The presence of iron concentrations, iron depletions, and crayfish burrows below a depth of $50 \mathrm{~cm}$, defines the udic soil moisture regime with the complete absence of redoximorphic features defining the ustic soil moisture regime below a MAP of $\sim 900 \mathrm{~mm}$.

Summary redoximorphic field data from microhighs reveal similarities and differences to the microlows across the climosequence (Fig. 11). Here, low chroma matrix colors also persist within the upper $50 \mathrm{~cm}$ through both the udic and ustic soil moisture regimes. Further, soft iron masses (nondiffuse) and depletions first appear just below and just above MAP of $1000 \mathrm{~mm}$, respectively. The key differences between the microhighs and microlows is that in the former soft iron masses with diffuse boundaries and crayfish burrows do not occur until about $1400 \mathrm{~mm}$ of MAP within the upper $50 \mathrm{~cm}$. Given that iron pore linings first appear at the same rainfall isohyet as in microlows, however, the transition from udic to aquic soil moisture regimes is more broadly defined in microhighs, occurring somewhere between 1276 and $1411 \mathrm{~mm}$ of MAP. The $\mathrm{Fe}_{o} / \mathrm{Fe}_{d}$ ratio is remarkably similar to that of the microlow in surface horizons indicating similar responses to regional climate trends. Redoximorphic attributes in udic soil moisture regimes of microhighs in the study area reveal the presence of iron concentrations and depletions below a depth of $50 \mathrm{~cm}$, except that these features are not as pervasive as in microlows. Microhighs in ustic soil moisture regimes are similar to microlows in that no redoximorphic features are present, regardless of depth, when MAP falls below $900 \mathrm{~mm}$.

Field morphological observations of redoximorphic features suggest that all soils in the study area forming in a rainfall belt of less than $1276 \mathrm{~mm}$ are either in the udic (Lake Charles 99TX 157-1, 99TX 481-1; all Laewest pedons) or the ustic (all Victoria pedons) soil moisture regimes. These soils also do not have sufficient redoximorphic features within the upper $100 \mathrm{~cm}$ for classification of aquic at the subgroup taxonomic level. Nonaquic conditions are supported by hydrological monitoring data of the microlow of a nearby Laewest pedon revealing that the upper $50 \mathrm{~cm}$ during the two-year monitoring period was never saturated nor reduced (Fig. 10). Further, the upper $100 \mathrm{~cm}$ according to water table data is not saturated for sufficient duration for the taxonomic placement of oxyaquic at the subgroup level. Thus, the Laewest taxonomy of Typic Hapludert and the Victoria taxonomy of Sodic Haplustert are verified in terms of soil moisture regime (Table 1).

The wetter League (all pedons) and Lake Charles (99TX 201-1) in our study area have sufficient quantities of iron redoximorphic features within the upper $50 \mathrm{~cm}$ to classify as aquic at the suborder level, especially when accompanied by protracted periods of saturation and a positive reaction to alpha, alpha'-dipyridil for an undetermined duration over an unspecified area of soil mass (Fig. 10). This supports field observations of aquic soil moisture regimes beginning at $\sim 1276 \mathrm{~mm}$ of MAP (Table 1), or more specifically as endoaquerts at the great group level because of long-term saturation throughout the solum (see Griffin, 1991). This aquert classification is in contrast to the current classification of these soils as uderts. The rationale for the original taxonomy of oxyaquic at the subgroup level for the League soils was the extended period of saturation accompanied by only short periods of reduction (Griffin, 1991; Jacob et al., 1997). 
Another view of wetness conditions for the League is a determination of whether the soils are hydric in terms of Federally protected jurisdictional wetlands (Environmental Laboratory, 1987). Because of the association of high color values with low chromas, iron pore linings within the upper $30 \mathrm{~cm}$, and a positive reaction to alpha, alpha'-dipyridil in the microlows of these soils would indeed qualify as hydric in the F3 category of Redox Dark Surface (USDA-NRCS, 1996). We cannot determine, with certainty, if the microhighs of these pedons are hydric because reaction to alpha, alpha'dipyridil was not tested in prior studies (Griffin, 1991). However, iron pore linings are in sufficient quantity that the microhighs would also classify as hydric, but in the F6 category of Depleted Matrix (USDA-NRCS, 1996). Further complicating these interpretations is that the three League pedons are in improved pasture preventing an assessment of potential hydrophytic vegetation.

\section{Hydropedological formation of vertisols}

Even though most iron concentrations and depletions increase in abundance and to shallower depths systematically across the climosequence, it is important to understand internal hydrological processes leading to the formation and distribution of redoximorphic features as part of the complex microlow and microhigh topography. Redoximorphic features indicative of periodic saturation and reduction first appear in the Laewest soils near $1000 \mathrm{~mm}$ of MAP and reach their maximum expression within the League soils on the eastern end of the climosequence. As a consequence, we examine in more detail a topographic microlow and microhigh for a composite Laewest and League profile to better understand the genesis of redoximorphic features as part of a conceptual hydropedological model (Fig. 12). These two groups of soils are also nearest to the monitoring stations of Griffin (1991; see Fig. 1).

Along the climosequence, the Laewest and League soils formed from parent materials containing high chroma colors, yet both have gray or grayish brown matrix colors in the upper part (Table 2). Depth to $>2$ chroma colors increases with increasing rainfall suggesting that the gray matrices are in quasi-equilibrium with contemporaneous wetness conditions. Interpretations of documented periods of saturation and reduction according to nearby monitoring data for the Laewest and League, however, are inconclusive regarding the dominance of gray matrix colors as contemporaneous or relict (Fig. 11). One explanation is that with greater rainfall, saturation is sufficient to reduce and mobilize iron, and then either transport the iron to greater depths where it is re-precipitated, or leached entirely from the profile, as confirmed qualitatively by Driese et al. (2005). Mass balance calculations for $\mathrm{Fe}_{d}$ and $\mathrm{Fe}_{o}$ for one of the League (00TX 245-1, Table 1) and one of the Lake Charles (99TX 157-1, Table 1) soils confirms this interpretation in both the microlow and microhigh (Driese, 2004). Thus we proceed under the assumption that the gray matrixes are in part the consequence of current periods of saturation and reduction of iron, particularly in microlows above $1276 \mathrm{~mm}$ of MAP. The difficulty of documenting pedogenic versus inherited soil color and its confounding influence on interpretations of wetness conditions is not uncommon (Genther et al., 1998; West et al., 1998; Rabenhorst and Parikh, 2000; Jacobs et al., 2002). Inherited colors are lithchromic, derived from the parent material, or derived from a former climate regime that was either wetter or drier than the present.

Redoximorphic features evaluated against matrix colors provide additional interpretive value for internal hydrological processes. Limited formation of iron redoximorphic features in the drier Laewest soils can be explained by a combination of factors (Fig. 12a): (1) high pH that lowers the redox potential needed for iron reduction; (2) low organic carbon reducing microbial respiration; (3) and brief periods of saturation mitigating anaerobic conditions (see Genther et al., 1998; West et al., 1998; Vepraskas, 2001). Below depths of $50 \mathrm{~cm}$ in microlows, a few redoximorphic features form in the Laewest that approximates the depth having the longest period of saturation according to monitoring data (Fig. 10a; Table 2). This redoximorphic distribution pattern in the Laewest soils is best explained by recent electrical resistivity surveys of moisture conditions extrapolated from a central Texas Houston Black soil ( $~ 800 \mathrm{~mm}$ MAP) where after a few rainfall events leading up to the month of July, 2005, water had preferentially collected in microlow bowls (Fig. 12). This is in agreement with the presence of well developed pedality, cracks, and slickensides in the upper profiles of the Laewest in our study area promoting non-Darcian by-pass flow. By-pass flow under these conditions diminishes the movement of water to ped interiors where they remain oxygenated (Blake et al., 1973; Anderson and Bouma, 1977a, b; Bouma et al., 1977; Bouma and Lovejoy, 1988; Lin et al., 1999). By-pass flow can penetrate to depths of greater than $2 \mathrm{~m}$ in a matter of days without saturating overlying zones even in subhumid to humid Vertisols (Blake et al., 1973; Lin and McInnes, 1995). This is consistent with recent work showing that $77 \%$ of the water is carried by only $3 \%$ of the porosity defined as $>0.5 \mathrm{~mm}$ pore diameter in some Vertisols (Lin et al., 1997).

The microhigh topographic position of the composite Laewest soil has only a few iron concentrations and at the same depth as those beneath the microlow bowls (Fig. 12a). The absence of redoximorphic features in the upper profile is not surprising given that microhighs serve as discharge zones. This is supported by the electrical resistivity panel in Fig. 12a showing that microhighs rarely saturate, but that at depth leakage from the bottom of microlow bowls, and along other deeply penetrating macrovoids, contributes to the formation of a differential water table causing localized reducing conditions. 


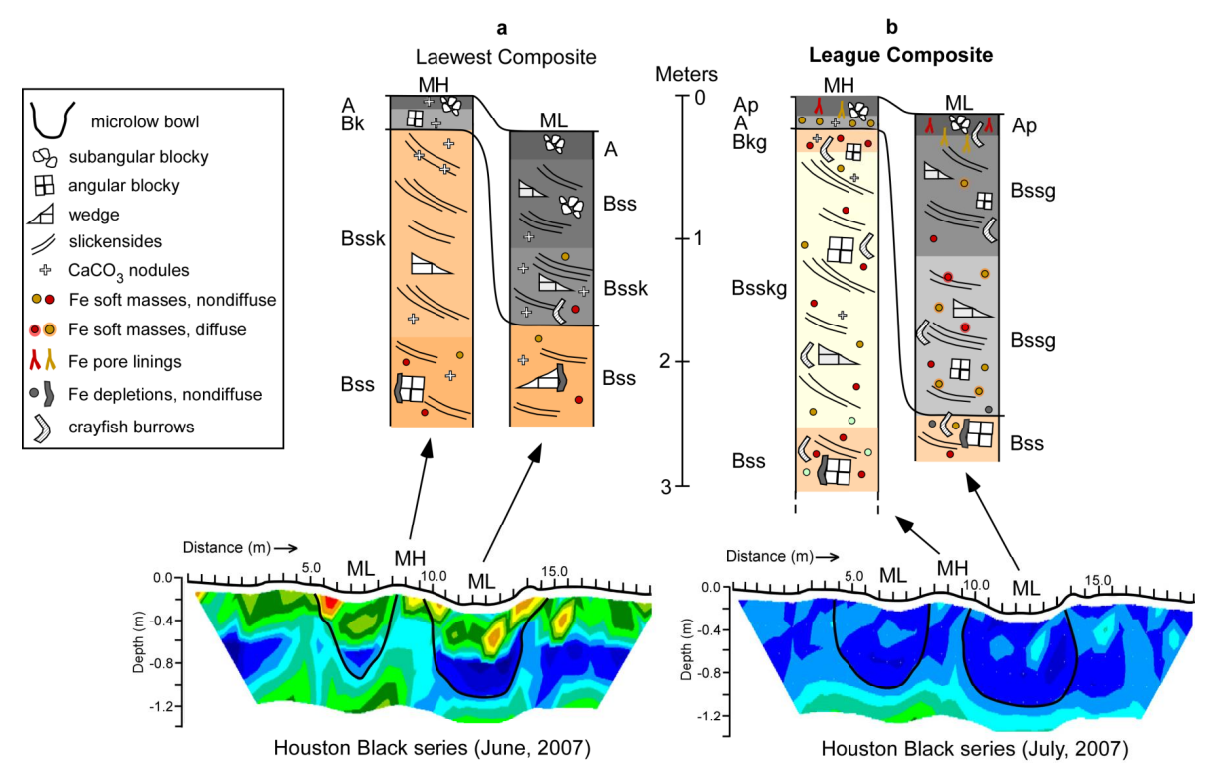

Fig. 12. Composite soil columns for the drier Laewest soil (a) and wetter League soil (b) illustrating the distribution of redoximorphic features used to develop the conceptual hydropedological model of Vertisol formation. Moisture distribution in the lower left panel of a central Texas upland Vertisol (Houston Black series) explains the distribution of water in the composite Laewest soils under typical wetting conditions. Moisture distribution in the lower right panel of the upland Vertisol after a protracted period of high rainfall explains the distribution of water in the composite League soils under typical wetting conditions (electrical resistivity panels modified from Amidu and Dunbar, 2007). Blue colors indicate near saturation conditions and red, orange, and yellow colors water held at or below the wilting point ( $<15$ bar suction). Note that the central Texas Vertisol has a shallower profile than the Laewest and League.

As with the Laewest, the upper part of the League soil also has well expressed structural properties, as evidenced by crayfish burrows, pedality, root channels, and slickensides (Table 2), but in the presence of water tables more frequently rising to the surface because of greater rainfall throughout the year (Fig. 10b). Figure 12b is the same central Texas Houston Black Vertisol discussed above one month later after several additional high intensity rainfall events. Here, the microlow bowls fill completely with water, with isolated saturated zones forming even in the surface horizons of microhighs. We speculate that this electrical resistivity panel represents conditions frequently attained in regions where MAP exceeds $1276 \mathrm{~mm}$, as in our study area. This explains the widespread distribution of iron concentrations with diffuse boundaries throughout the League microlow and the presence of iron pore linings in surface horizons of both the microlow and microhigh. Iron pore linings are perhaps the most reliable indicator of contemporary anaerobic conditions and the presence of hydrophytic plants (Chen et al., 1980; Mendelssohn et al., 1995).

Our hydropedological model also accounts for the distribution of iron redoximorphic features in relation to voids. Once microlow bowls fill with water and reach a state of semi-equilibrium, free water stacks in overlying macrovoids forming iron depletions on ped faces with reduced iron diffusing into oxygenated ped interiors where it forms soft masses. Iron depletions also form below the microlow bowls, and below microhighs at similar depths, along macrovoids that serve as water conduits, thereby forming soft iron masses by diffusion into ped interiors. Here, iron depleted macrovoids are more widely spaced because of the increase in size and decrease in strength of structural aggregates in this zone, accompanied by a decrease in rooting (Table 2 ). The process of capillary flow upward and downward from the perched water table in the microlow helps explain the presence of some gray ped interiors and soft iron masses on ped exteriors (Vepraskas, 2001) in both the Laewest and League soils.

Soft iron masses with nondiffuse boundaries in the microlow of the Laewest, and in the microhigh of both the Laewest and League soils, suggest that these features did not form in their current position with respect to the distribution of macrovoids (Vepraskas, 2001). Lateral shifting of soft iron masses from the microlow to microhigh during shrink-swell processes may have reworked the boundaries of these features from diffuse to nondiffuse (Fig. 11). The distribution of calcium carbonate nodules following thrust zones from deep in microlows up along master slickensides towards the surface of the adjacent microhighs supports this interpretation (see Miller et al., 2007).

Regarding extractable forms of iron oxides, the $\mathrm{Fe}_{d}$ phase is in greater abundance and should include crystalline species that based on color of the existing soft iron masses and pore linings, is likely goethite and lepidocrocite (Schwertman, 
1993). $\mathrm{Fe}_{d}$ evidently increases at a more rapid rate than $\mathrm{Fe}_{o}$ because $\mathrm{Fe}_{d}$ has been accumulating in response to regional climate over a longer time period. $\mathrm{Fe}_{o}$, on the other hand, leads to the formation of noncrystalline iron oxides, such as ferrihydrite, that may form and dissolve on a seasonal time scale. Of note is the more rapid increase in $\mathrm{Fe}_{d}$ with rainfall in microhighs at both the surface and at a depth of $100 \mathrm{~cm}$, possibly because of fewer reduction intervals preserving the most stable forms of iron oxide.

\section{Summary and conclusions}

A number of important hydropedological conclusions are drawn from the results of this investigation along the Vertisol climosequence on the Gulf Prairie Land Resource Area of Texas.

1. Matrix colors within the upper $1 \mathrm{~m}$ exhibit gray colors in all soil moisture regimes, but because of increased saturation and reduction accompanied by greater depth to high chroma colors in relation to rainfall, it is hypothesized that the gray colors are at least in part contemporaneous features when MAP is $>1276 \mathrm{~mm}$.

2. Soft iron masses and depletions and crayfish burrows first appear and in microlows, but below a depth of $50 \mathrm{~cm}$, once MAP of $\sim 1000 \mathrm{~mm}$ is attained. These features increase in abundance and begin forming within the upper $50 \mathrm{~cm}$ by $1276 \mathrm{~mm}$ of MAP.

3. $\mathrm{Fe}_{d}$ and $\mathrm{Fe}_{o}$ extractable iron oxides reveal a strong correlation to increasing rainfall in surface horizons as a constant $\mathrm{Fe}_{d} / \mathrm{Fe}_{o}$ ratio with $\mathrm{Fe}_{d}$ dominating. $\mathrm{Fe}_{d}$ appears to document long-term pedogenic accumulation as a product of weathering as rainfall increases in well drained environments. $\mathrm{Fe}_{o}$ reflects short-term, seasonal precipitation/dissolution processes of amorphous minerals.

4. Soils on the drier end of the climosequence agree with the current taxonomy of the Victoria and Laewest series (Sodic Haplustert and Typic Hapludert, respectively). Two of the Lake Charles pedons in the middle of the climosequence also classify according to current taxonomic placement (Typic Hapludert). However, all soils forming where MAP $\geq 1276 \mathrm{~mm}$ appear to classify as Typic Endoaquerts rather than either Typic Hapluderts (Lake Charles, 99TX 201-1) or Oxyaquic Hapluderts (League). The latter group of soils also fit the criteria for hydric soil status as part of jurisdictionally-defined wetlands. Mitigating these interpretations is the disequilibrium between protracted intervals of saturation and short-term duration of reduction.
5. Soils formed in Ustic soil moisture regimes $(<900$ mm MAP) never develop redoximorphic features. Those formed in Udic soil moisture regimes ( $~ 900$ to $1276 \mathrm{~mm}$ MAP) exhibit redoximorphic features, but only below a depth of $50 \mathrm{~cm}$. Those soils with redoximorphic features within the upper $50 \mathrm{~cm}$ appear to have aquic soil moisture regimes coinciding with MAP of $>1276$.

6. Even though soft iron masses with diffuse boundaries form commonly in microlows and those with nondiffuse boundaries typically in microhighs, their depth of occurrence show a remarkably strong, inverse correlation with MAP. This complicates the interpretation of whether soft iron masses with nondiffuse boundaries are relict or contemporaneous features.

7. All soils appear to wet according to non-Darcian bypass flow along cracks and master slickensides such that microlow bowls are first filled with water. Between $\sim 900$ and $1276 \mathrm{~mm}$ of MAP water tables commonly form below depths of $50 \mathrm{~cm}$, coincidental with the presence of iron redoximorphic features. Microhighs have no redoximorphic features except at great depths. Above MAP of 1276 the microlow bowls commonly fill with water, and to the surface, resulting in the formation of redoximorphic features at all depths in both the microlow and microhigh.

8. Most iron depletions form along void walls as part of the process of bypass flow, accompanied by a preponderance of soft iron masses in ped interiors. However, above the perched water table in microlow bowls capillary action projects water through ped interiors where iron is reduced, followed of precipitation along void walls. Iron depleted soft masses and pores also form along ped faces and channels at depth from leakage from microlow bowls with reduced iron diffusing to ped interiors precipitations as soft masses.

Further water table monitoring studies associated with redox potentials and iron reduction dyes need to be systematically performed on Vertisol microlows and microhighs in the coast prairie of Texas. Of particular importance would be long-term monitoring to capture the norm of the natural seasonal climate variability. Detailed three-dimensional mapping of redoximorphic features in both microlows and microhighs should support these studies to better model water flow, saturation, and reduction in these complex landscapes. As one example, pit walls of adjacent microlows and microhighs should be excavated perpendicular to each other in both profile and plan view to examine spatial hydrological changes occurring horizontally and vertically. These additional studies would strengthen taxonomic and hydric placement of these problematic soils regarding wetness conditions. 
Acknowledgements. The authors are grateful for many fruitful discussions regarding the hydropedology of Vertisols with Jon Wiedenfeld and Wes Miller, current and former, employees of the USDA-NRCS. We also thank Henry Lin for his leadership in the field of hydropedology and for organizing the recent critical zone hydropedology conference at Penn State University. We also acknowledge the USDA-NRCS National Soil Survey Laboratory in Lincoln, Nebraska for assistance with soil characterization, as well as the support of the National Science Foundation through grant EAR-9814607 awarded to the authors, which funded initial Texas Coast Prairie Vertisol climosequence research. We are especially indebted to Craig Rasmussen, Maria Nobles, and Henry Lin for providing valuable comments that improved the manuscript.

Edited by: H. Lin

\section{References}

Amidu, S. A. and Dunbar, J. A.: Geoelectric studies of seasonal wetting and drying of a Texas Vertisol, Vadose Zone Journal, 6, 511-523, 2007.

Anderson, J. L. and Bouma, J.: Water movement through pedal soils, I. Saturated flow, Soil Sci. Soc. Am. J., 41, 413-418, 1977a.

Anderson, J. L. and Bouma, J.: Water movement through pedal soils, II. Unstructured flow, Soil Sci. Soc. Am. J., 41, 419-423, 1977b.

Barnes, V.: Geologic Atlas of Texas, Beeville-Bay City Sheet, Bureau of Economic Geology, The University of Texas at Austin, 1987.

Blake, G., Schlichting, E., and Zimmermann, U.: Water recharge in soil with shrinkage cracks, Soil Sci. Soc. Am. J., 37, 669-672, 1973.

Blum, M. and Price, D.: Glacio-eustatic and climate controls on Pleistocene alluvial plain deposition, Texas coastal plain, Gulf Coast Association of Geological Societies Transactions 44, 8592, 1994.

Bouma, J. and Lovejoy, J.: Characterizing soil water regimes in swelling clay soils, in: Vertisols: Their Distribution, Properties, Classification, and Management, edited by: Wilding, L. P. and Puentes, R., Technical Monograph No. 18, Texas A\&M University Printing Center, College Station, Texas, 83-95, 1988.

Bouma, J., Jongerius, A., Boersma, O., Jager, A., and Schoonderbeek, D.: The function of different types of macropores during saturated flow through four swelling soil horizons, Soil Sci. Soc. Am. J., 41, 945-950, 1977.

Chen, C. C., Dixon, J. B., and Turner, F. T.: Iron coatings on rice roots: mineralogy and quantity influencing factors, Soil Sci. Soc. Am. J., 44, 635-639, 1980.

Coulombe, C., Wilding, L., and Dixon, J. B.: Overview of Vertisols: characteristics and impacts on society, Advances in Agronomy, Volume 57, Academic Press, New York, 289-375, 1996.

Comerma, J. A.: Hydromorphic vertisols, in: Wetland Soils: Characterization, Classification, and Utilization, Proceedings of a Workshop, Manila, Philippines, 26 March-5 April, 1984, International Rice Research Institute, Manila, Philippines, 407-420, 1985.

Driese, S. G.: Pedogenic translocation of Fe in modern and ancient Vertisols and implications for interpretations of the Hekpoort paleosol (2.25 Ga), J. Geol., 112, 543-560, 2004.
Driese, S. G., Nordt, L. C., Lynn, W. C., Stiles, C. A., Mora, C. I., and Wilding, L. P.: Distinguishing climate in the soil record using chemical trends in a Vertisol climosequence from the Texas Coastal Prairie, and application to interpreting Paleozoic paleosols in the Appalachian basin, J. Sediment. Res., 75, 339-349, 2005.

Dudal, R. and Eswaran, H.: Distribution, properties and classification of Vertisols, in: Vertisols: Their Distribution, Properties, Classification, and Management, edited by: Wilding, L. P. and Puentes, R., Technical Monograph No. 18, Texas A\&M University Printing Center, College Station, Texas, 1-22, 1988.

Environmental Laboratory: Corps of Engineers wetlands delineation manual, Technical Report Y-87-1, US Army Engineering Waters Experiment Station, Vicksburg, Mississippi, 1987.

Genther, M. H., Daniels, W. L., Hodges, R. L., and Thomas, P. J.: Redoximorphic features and seasonal water table relations, upper coastal plain, Virginia, in: Quantifying Soil Hydromorphology, edited by: Rabenhorst, M. C., Bell, J. C., and McDaniel, P. A., Soil Science Society of America Special Publication No. 54, Madison, Wisconsin, 43-60, 1998.

Guo, Y., Amundson, R., Gong, P., and Yu, Q.: Quantity and spatial variability of soil carbon in the conterminous United States, Soil Sci. Soc. Am. J., 70, 590-600, 2006.

Griffin, R. G.: A study of aquic conditions of seasonally wet soils on the coast prairie of Texas, Ph.D. dissertation, Texas A\&M University, College Station, Texas, 314 pp., 1991.

Hasiotis, S. T. and Mitchell, C. E.: A comparison of crayfish burrow morphologies: Triassic and Holocene fossil, paleo- and neoichnological evidence and the identification of their burrowing signatures, Ichnos, 2, 291-314, 1993.

Jacob, J. S., Griffin, R. W., Miller, W. L., and Wilding, L. P.: Aquerts and aquertic soils: a querulous proposition, in: Aquic Conditions and Hydric Soils: The Problems Soils, edited by: Vepraskas, M. J. and Sprecher, S. W., Soil Science Society of America Special Publication No. 50, Madison, Wisconsin, 6177, 1997.

Jacobs, P. M., West, L. T., and Shaw, J. N.: Redoximorphic features as indicators of seasonal saturation, Loundes County, Georgia, Soil Sci. Soc. Am. J., 66, 315-323, 2002.

Lin, H. S. and McInnes, K. J.: Water flow in clay soil beneath a tension infiltrometer, Soil Science, 159, 375-382, 1995.

Lin, H. S., McInnes, K. J., Wilding, L. P., and Hallmark, C. T.: Low tension water flow in structured soils, Can. J. Soil Sci., 77, 649-654, 1997.

Lin, H. S., McInnes, K. J., Wilding, L. P., and Hallmark, C. T.: Effects of soil morphology on hydraulic properties: I. Quantification of soil morphology, Soil Sci. Soc. Am. J., 63, 948-954, 1999.

Mendelssohn, I. A., Kleiss, B. A., and Wakeley, J. S.: Factors controlling the formation of oxidized root channels: a review, Wetlands, 15, 37-46, 1995.

Miller, D. L., Mora, C. I., and Driese, S. G.: Isotopically concentric growth in large carbonate nodules in Vertisols: implications for climate and ecosystem assessments, Geoderma, 142, 104-111, 2007.

Miller, W.: Soil Survey of Jackson County, Texas, USDA-NRCS, Washington DC Printing Press, 1997.

Nordt, L., Orosz, M., Driese, S., and Tubbs, J.: Vertisol carbonate properties in relation to mean annual precipitation: implications 
for paleoprecipitation estimates, J. Geol., 114, 501-510, 2006.

Nordt, L., Wilding, L., Lynn, W. L., and Crawford, C.: Vertisol genesis in a humid climate in the coastal plain of Texas, Geoderma, 122, 83-102, 2004.

Nordt, L. and Wilding, L.: Organic carbon stocks and sequestration potential of Vertisols in the Coast Prairie Land Resource Area of Texas, in: Soil Carbon Sequestration and the Greenhouse Effect, edited by: Lal, R. and Follett, R., Soil Science Society of America Special Publication 57, second edition, Madison, Wisconsin, 159-168, 2009.

Rabenhorst, M. C. and Parikh, S.: Propensity of soils to develop redoximorphic color changes, Soil Sci. Soc. Am. J., 64, 19041910, 2000.

Schoeneberger, P. J., Wysocki, D. A., Benham, E. C., and Broderson, W. D. (Eds.): Field book for describing and sampling soils, Version 2.0, Natural Resources Conservation Service, National Soil Survey Center, Lincoln, Nebraska, 2002.

Schwertmann, U.: Relations between iron oxides, soil color, and soil formation, in: Soil Color, edited by: Bigham, J. M. and Ciolkosz, E. J., Soil Science Society of America Special Publication Number 31, Madison, Wisconsin, 51-70, 1993.

Soil Survey Division Staff: Soil Survey Manual, US Department of Agriculture Handbook 18, US Government Printing Office, Washington, 437 pp., 1993.

Soil Survey Staff: Soil Taxonomy: A basic system of soil classification for making and interpreting soil surveys, USDA-NRCS Agriculture Handbook 436, $2^{\text {nd }}$ edition, U.S. Government Printing Office, Washington, 869 pp., 1999.

Soil Survey Staff: Soil Survey Laboratory Methods Laboratory, Soil Survey Investigations Report No. 42, USDA-NRCS National Soil Survey Center, Lincoln, Nebraska, 700 pp., 1994.
Soil Survey Staff: National Soil Series Characterization Data and Soil Survey Laboratory, USDA-NRCS National Soil Survey Center, Lincoln, Nebraska, online available at: http://ssldata. nrcs.usda.gov, 2009.

Stone, E. L.: Soil burrowing and mixing by a crayfish, Soil Sci. Soc. Am. J., 57, 1096-1099, 1993.

USDA-SCS: Land resource regions and major land resource areas of the United States, Agricultural Handbook 18, US Government Printing Office, Washington DC Printing Press, 1981.

USDA-NRCS: Soil Survey Laboratory Information Manual, Soil Survey Investigations Report 42, Version 3.0, US Government Printing Office, Washington, DC, 305 pp., 1995.

USDA-NRCS: Field indicators of hydric soils in the United States, Version 3.2, edited by: Hurt, G. W., Whited, P. M., and Pringle, R. F., USDA-NRCS, Fort Worth, Texas, 27 pp., 1996.

Vepraskas, M. J.: Morphological features of seasonally reduced soils, in: Wetland Soils: Genesis, Hydrology, Landscapes, and Classification, edited by: Vepraskas, M. J. and Richardson, J. L., Lewis Publishers: Boca Raton, Florida, 163-182, 2001.

West, L. T., Shaw, J. N., Blood, E. R., and Kirkman, L. K.: Correlation of water tables to redoximorphic features in the Dougherty Plain, Southwest Georgia, in: Quantifying Soil Hydromorphology, edited by: Rabenhorst, M. C., Bell, J. C., and McDaniel, P. A., Soil Science Society of America Special Publication Number 54, Madison, Wisconsin, 247-258, 1998.

Wilding, L. P. and Tessier, D.: Genesis of Vertisols: shrink-swell phenomena, in: Vertisols: Their Distribution, Properties, Classification, and Management, edited by: Wilding, L. P. and Puentes, R., Technical Monograph No. 18, Texas A\&M University Printing Center, College Station, Texas, 55-81, 1988. 